\title{
Home Office in the COVID-19 Pandemic: Impacts on Human Behavior
}

ISSN: 2578-0042

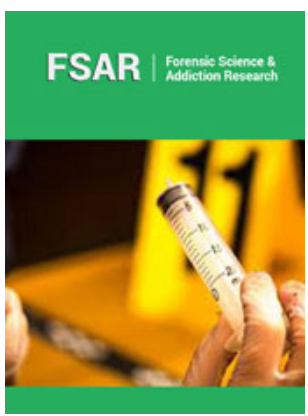

*Corresponding author: Lucio Lage Gonçalves,Laboratory DeleteDigital Detox and Conscious Use of Technologies, Institute of Psychiatry (IPUB), Federal University of Rio de Janeiro (UFRJ), Rio de Janeiro, RJ, Brazil

Submission: 傮 September 09, 2020

Published: 眥 November 09, 2020

Volume 5 - Issue 3

How to cite this article: Lucio Lage Gonçalves, Antonio Egidio Nardi, AnnaLucia Spear King. Home Office in the COVID-19 Pandemic: Impacts on Human Behavior. Forensic Sci Add Res. 5(3). FSAR.000617.2020.

DOI: 10.31031/FSAR.2020.05.000617

Copyright@ Lucio Lage Gonçalves, This article is distributed under the terms of the Creative Commons Attribution 4.0 International License, which permits unrestricted use and redistribution provided that the original author and source are credited.

\author{
Lucio Lage Gonçalves ${ }^{1 *}$, Antonio Egidio Nardi ${ }^{2}$ and AnnaLucia Spear King ${ }^{1}$
}

${ }^{1}$ Laboratory Delete-Digital Detox and Conscious Use of Technologies, Institute of Psychiatry (IPUB), Federal University of Rio de Janeiro (UFRJ), Rio de Janeiro, RJ, Brazil

${ }^{2}$ Laboratory Panic and Respiration, Institute of Psychiatry (IPUB), Federal University of Rio de Janeiro (UFRJ), Rio de Janeiro, RJ, Brazil

\begin{abstract}
Objective: Describe objectively the possibilities of physical and psychological impacts due to working conditions in the home office during social isolation by COVID-19.

Method: Literature review in the last ten years addressing the unprecedented condition of working at home office in social isolation.

Results: The findings showed that physical impacts such as vision problems and functional limitations can occur. Loneliness due to lack of face-to-face contact with other people can develop anxiety, depression and binge eating.
\end{abstract}

Conclusion: The home office in social isolation can provide physical and psychological impacts due to the conditions of the homework environment

Keywords: Home office; COVID-19; Pandemic; Human behavior; Social isolation

\section{Introduction}

Impacts on human behavior are relevant when changes in the routine of individuals occur, requiring changes in habits and ways of relating, especially when conditions of isolation are imposed. Pandemics and epidemics can affect people's physical and emotional health and disrupt society, usually resulting in a high level of psychological distress and psychosocial maladjustment [1].

Social isolation tends to provoke psychological reactions, such as increased levels of anxiety, stress and irritability, propitiate the appearance of fears (based on real or subjective information) and confused thinking, affecting negatively the individual's ability to make coherent decisions [2]. The impacts of social isolation on physical and mental well-being are well known. Isolation, loneliness, among other behaviors and feelings, tend to affect individuals as well as those around them, and this is especially the case during the COVID-19 pandemic [3]. In terms of commuting limitations, professional activity in the Home Office modality has become "savior" of jobs, companies, businesses, ensuring continuity of work, remotely, even though not all people have ideal conditions to work at home. The lack of these conditions can, over time, have consequences on human behavior and cause changes in the general well-being of the subjects.

\section{Physical impacts}

Digital Ergonomics needs to be observed, as physical damage related to improper postures and incorrect furniture when using devices from the digital world at home, can cause damage [4]. The improper handling of computers, cell phones, tablets, among others, has favored the appearance of pathologies and functional physical limitations that are being observed more frequently in medical offices [5]. The phototoxicity of violet light from digital devices can lead to progressive degeneration of the macula, a noble area of vision, which can cause irreversible damage to individuals exposed continuously and prolonged to this luminosity [6]. 


\section{Face-to-face solitude}

Loneliness and social isolation are living conditions that can increase the likelihood of mental disorders such as depression, anxiety, substance use and cognitive decline [7]. Loneliness shakes people's ability to self-regulate and represents the pain of feeling alone [8]. Working from home office requires constant evaluation in all aspects. We must observe if the individual is able to withstand the repetition of work at home, daily, the absence of colleagues to talk in person, in addition to the feeling of disconnection with the organization or group to which he belongs. It is possible to lose control of time, due to not sharing it with other people, aggravated by the excessive use of digital technologies, reinforcing the solitary character of the home office, which can lead to behavioral changes harmful to health. The opposition between coexistence and isolation is intensified by the role of new communication technologies and social networks that fix the individual in front of screens [9].

\section{Food compulsion}

Eating disorders are a group of conditions characterized by persistent disturbances in food or behaviors related to it, which result in changes in the consumption or absorption of food, impairing physical health and psychosocial functioning [10]. Home office workplaces individuals too close to the refrigerator and pantry and, being at home, requires a lot of determination to stick to mealtimes, in choosing what to eat and in what quantities. It is really surprising that we use ice cream and other fatty foods when we are sitting at home feeling totally alone in the world [8]. The home office can be a reinforcing or revealing vector of eating disorders due to one of its characteristics, which is isolation in the development of work

\section{Disclosure}

The authors declare no conflicts of interest.

\section{References}

1. Zhang J, Wu W, Zhao X, Zhang W (2020) Recommended psychological crisis intervention response to the 2019 novel coronavirus pneumonia outbreak in China: A model of West China Hospital. Precis Clin Med 3(1): 3-8.

2. Bao Y, Sun Y, Meng S, Shi J, lu l (2020) 2019-nCOVID epidemic: Address mental health care to empower society. Lancet 395(10224): e37-38.

3. Carta MG, Nardi AE, Bhugra D (2020) New technologies for social inclusion of people with psychosocial disabilities in the era of COVID-19 and beyond. Braz J Psychiatry.

4. King ALS, Páua MK, Guedes E, Nardi AE (2018) Digital ergonomics. Porto Alegre, Educa Books, Brazil.

5. King ALS, Valença AM, Silvia ACO, Baczynski T, Carvalho MR, et al. (2015) Nomophobia: Dependency on virtual environments or social phobia? Computers in Human Behavior 29(1): 140-144.

6. Molina VJG (2017) Blue light: From scientific evidence to patient care. International Review of Ophthalmic Optics, pp. 88-94.

7. Leigh-Hunt N, Baggueley D, Bash K (2012) An overview systematic reviews of social isolation and loneliness. Public Health 152: 157-171.

8. Cacciopo J, Patrick W (2011) Solitude: Human nature and the needs for bonds, (1 $1^{\text {st }}$ edn), São Paulo, Record, Brazil.

9. Minois G (2019) History of loneliness and loners. Translation M, Graças Souza, ( $1^{\text {st }}$ edn), São Paulo, UNESP, Brazil.

10. American Psychological Association (2013) Diagnostic and Statistical Manual of Mental Disorders-DSM-V, Translation Claudia Dorneles, $\left(5^{\text {th }}\right.$ edn), Porto Alegre, Artmed, Canada. 